\title{
A Novel Chemical Profile of a Selective In Vitro Cholinergic Essential Oil from Clinopodium taxifolium (Kunth) Govaerts (Lamiaceae), a Native Andean Species of Ecuador
}

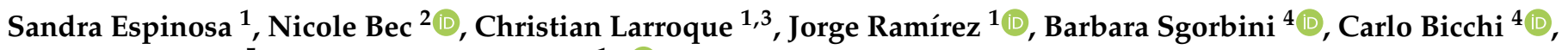 \\ Nixon Cumbicus ${ }^{5}$ and Gianluca Gilardoni ${ }^{1, * \text { (D) }}$ \\ 1 Departamento de Química y Ciencias Exactas, Universidad Técnica Particular de Loja, Loja 1101608, Ecuador; \\ etsandra1@gmail.com (S.E.); cjlarroque@gmail.com (C.L.); jyramirez@utpl.edu.ec (J.R.) \\ IRMB, Université de Montpellier, INSERM, 34298 Montpellier, France; nicole.bec@inserm.fr \\ 3 Supportive Care Unit, Institut du Cancer de Montpellier (ICM), 34298 Montpellier, France \\ 4 Dipartimento di Scienza e Tecnologia del Farmaco, Università degli Studi di Torino, 10125 Torino, Italy; \\ barbara.sgorbini@unito.it (B.S.); carlo.bicchi@unito.it (C.B.) \\ 5 Departamento de Ciencias Biológicas, Universidad Técnica Particular de Loja (UTPL), Loja 1101608, Ecuador; \\ nlcumbicus@utpl.edu.ec \\ * Correspondence: ggilardoni@utpl.edu.ec or gianluca.gilardoni@gmail.com
}

Citation: Espinosa, S.; Bec, N.; Larroque, C.; Ramírez, J.; Sgorbini, B.; Bicchi, C.; Cumbicus, N.; Gilardoni, G. A Novel Chemical Profile of a Selective In Vitro Cholinergic Essential Oil from Clinopodium taxifolium (Kunth) Govaerts (Lamiaceae), a Native Andean Species of Ecuador. Molecules 2021, 26, 45. https://dx.doi.org/10.3390/ molecules26010045

Academic Editor: Gianni Sacchetti Received: 30 November 2020 Accepted: 20 December 2020 Published: 23 December 2020

Publisher's Note: MDPI stays neutral with regard to jurisdictional claims in published maps and institutional affiliations.

Copyright: () 2020 by the authors. Licensee MDPI, Basel, Switzerland. This article is an open access article distributed under the terms and conditions of the Creative Commons Attribution (CC BY) license (https: / / creativecommons.org/ licenses/by/4.0/).

\begin{abstract}
A novel chemical profile essential oil, distilled from the aerial parts of Clinopodium taxifolium (Kunth) Govaerts (Lamiaceae), was analysed by Gas Chromatography-Mass Spectrometry (GC-MS, qualitative analysis) and Gas Chromatography with Flame Ionization Detector (GC-FID, quantitative analysis), with both polar and non-polar stationary phase columns. The chemical composition mostly consisted of sesquiterpenes and sesquiterpenoids $(>70 \%)$, the main ones being $(E)$ - $\beta$-caryophyllene (17.8\%), $\alpha$-copaene (10.5\%), $\beta$-bourbonene (9.9\%), $\delta$-cadinene $(6.6 \%)$, cis-cadina- $1(6), 4$-diene $(6.4 \%)$ and germacrene $\mathrm{D}(4.9 \%)$, with the non-polar column. The essential oil was then submitted to enantioselective GC analysis, with a diethyl-tert-butyldimethylsilyl- $\beta$-cyclodextrin diluted in PS-086 chiral selector, resulting in the following enantiomeric excesses for the chiral components: $(1 R, 5 S)-(-)-\alpha$-thujene $(67.8 \%),(1 R, 5 R)-(+)-\alpha$-pinene $(85.5 \%),(1 S, 5 S)-(-)-\beta$-pinene $(90.0 \%),(1 S, 5 S)-(-)$-sabinene $(12.3 \%),(S)-$ (-)-limonene (88.1\%), (S)-(+)-linalool (32.7\%), (R)-(-)-terpinen-4-ol (9.3\%), (S)-(-)- $\alpha$-terpineol (71.2\%) and $(S)-(-)$-germacrene $\mathrm{D}(89.0 \%)$. The inhibition activity against acetylcholinesterase (AChE) and butyrylcholinesterase (BChE) of $C$. taxifolium essential oil was then tested, resulting in selective activity against $\mathrm{BChE}$ with an $\mathrm{IC}_{50}$ value of $31.3 \pm 3.0 \mu \mathrm{g} / \mathrm{mL}$ (positive control: donepezil, $\mathrm{IC}_{50}=3.6 \mu \mathrm{g} / \mathrm{mL}$ ).
\end{abstract}

Keywords: Clinopodium taxifolium; Gardoquia taxifolia; Satureja taxifolia; essential oil; GC-MS; GC-FID; enantioselective analysis; AChE; BChE; Ecuador

\section{Introduction}

According to the UN Environment Program World Conservation Monitoring Centre [1], Ecuador belongs to the group of the 17 megadiverse countries in the world, making it an extraordinary reservoir of biodiversity. As a megadiverse country, it must possess "at least 5000 of the world's plants as endemics" [1]. Most of the botanical species described in Ecuador have never been studied so far from a phytochemical point of view; this makes the country an unbelievable source of potentially new chemical structures and biologically active compounds. In 2016, two of us (J.R. and G.G.) reported that about $50 \%$ of all the phytochemical publications on the Ecuadorian flora referred only to 8 of the 245 botanical families of the native species known in the country [2]. For this reason, the authors have been involved for years in the description of specialized (secondary) metabolites contained in the Ecuadorian flora, to contribute to the advance in its phytochemical and phytopharmaceutical knowledge [3-10]. Within a project focused on the description of new essential oils (EOs) [11-20], the aim of this study is to describe a novel 
chemical profile of an already known EO, distilled from the aerial parts of Clinopodium taxifolium (Kunth) Govaerts. Clinopodium taxifolium (Kunth) Govaerts is a species belonging to the family Lamiaceae, also known with many synonyms, such as Gardoquia taxifolia Kunth, Satureja andrei Epling, Satureja taxifolia (Kunth) Briq., Gardoquia glabrata Kunth, Thymus taxifolius Willd. ex Benth, Satureja glabrata (Kunth) Briq., Satureja taxifolia (Kunth) Briq. and Satureja lineata Epling. [10,21-23]. This plant is also known with the homonym Clinopodium taxifolium (Kunth) Harley [21]. The species is native of the Andean region of Ecuador [23], where it has been described in the provinces of Azuay, Oro y Loja. However, specimens have also been described in Bolivia and Peru [21]. This plant grows at an altitude of 1500-3000 m above sea level [23] and it is known as Culantrillo de Cerro or Polea de Castilla [10]. Furthermore, C. taxifolium is used by infusion in folk medicine for treating internal inflammations, flatulence, stomach pain, malaria and cough [10]. In 2018, one of the authors (G.G.) first published the composition of an EO from this species as a part of a phytochemical study [10]. Afterwards, the authors studied the composition of the $\mathrm{EO}$ of a different sample of $C$. taxifolium of different origin, obtaining very different quali-quantitative and general sensory results, compared to that described in 2018. The EO was therefore re-investigated on a statistically significant number of samples, rigorously identified from the botanic point of view and submitted to new biological essays.

The inhibition activity of a cholinesterase (ChE) was here investigated, within a project focused on the identification of plant specialized metabolites active against Alzheimer's disease (AD). AD is a chronic neurodegenerative illness, characterized by a progressive deterioration of memory and cognitive functions. According to the World Health Organization $(\mathrm{WHO}), \mathrm{AD}$ is currently the first cause of dementia in the world, being responsible for $60-70 \%$ of cases [24]. The universal interest in finding new anti-AD drugs is due to the rapid diffusion of this illness in western countries, mainly as a consequence of the increase in life expectancy. The 2016 World Alzheimer's Report indicated that 47 million people live with dementia worldwide, and this number is expected to increase to more than 131 million by the year 2050. The disease is due to the accumulation of anomalous protein fragments (amyloid $\beta$ peptides and hyper-phosphorylated tau proteins) into the brain. Several hypotheses try to explain this phenomenon, the most important of them being the so-called cholinergic hypothesis Accordingly, the cognitive degradation is due to the destruction of cholinergic neurons and the consequent $\mathrm{ChE}$ depletion, which can be counteracted by inhibiting the acetylcholinesterase (AChE) and butyrylcholinesterase (BChE) enzymes [24]. The administration of $\mathrm{ChE}$ inhibitors has been shown to produce an increase in the levels of acetylcholine (ACh) in the brain [25,26], counteracting the progress of the symptoms. The present discussion on the effectiveness and availability of drugs to treat $\mathrm{AD}[27,28]$, is the basis for the investigation of natural products in this field [26].

To the best of the authors' knowledge, the present study is the first description of these chemical profile and biological activity of an EO distilled from C. taxifolium.

\section{Results}

\subsection{Chemical Analysis}

The EO was obtained in a quite low yield $(0.07 \pm 0.02 \%)$ from fresh plant material. A total of 37 compounds were detected, of which 32 with a non-polar Gas Chromatography (GC) column and 36 on a polar column. Most of the detected constituents were identified according to the corresponding Electron Ionization Mass Spectrum (EIMS) and Linear Retention Index (LRI). Two sesquiterpene hydrocarbons (204 amu) and one sesquiterpene alcohol (220 amu) could not be identified (unknown). The component abundance, here reported for both GC on non-polar (first value) and polar columns (second value), was measured by normalized percent abundance. The abundance of a total of 34 components was determined with at least one column, obtaining values corresponding to $88.1 \%$ and $86.0 \%$ of the whole sample, respectively, with a detection threshold fixed at $0.1 \%$. The chemical analysis showed that this EO mainly consisted of sesquiterpenes and sesquiterpenoids (more than $70 \%$ ), the main ones being (E)- $\beta$-caryophyllene (17.8-14.5\%), $\alpha$-copaene (10.5-8.0\%), 
$\beta$-bourbonene (9.9-8.2\%), $\delta$-cadinene (6.6-5.4\%), cis-cadina-1(6),4-diene (6.4-0.2\%) and germacrene $\mathrm{D}(4.9-4.9 \%)$. The full chemical composition is reported in Table 1.

Table 1. Chemical composition of $C$. taxifolium EO with 5\%-phenyl-methylpolysiloxane (DB-5ms) and polyethylene glycol (INNOWax) columns.

\begin{tabular}{|c|c|c|c|c|c|c|c|c|c|}
\hline \multirow{2}{*}{$\mathbf{N}^{\circ}$} & \multirow{2}{*}{ Component } & \multicolumn{4}{|c|}{ DB-5ms } & \multicolumn{4}{|c|}{ HP-INNOWax } \\
\hline & & LRI $^{a}$ & LRI $^{b}$ & $\%^{c}$ & $\sigma^{d}$ & $\operatorname{LRI}^{a}$ & LRI $^{b}$ & $\%^{c}$ & $\sigma^{d}$ \\
\hline 1 & $\alpha$-thujene & 919 & 924 [29] & trace & - & 1022 & 1025 [30] & trace & - \\
\hline 2 & $\alpha$-pinene & 925 & 932 [29] & 0.7 & 0.22 & 1017 & 1020 [31] & 0.4 & 0.19 \\
\hline 3 & sabinene & 965 & 969 [29] & 3.2 & 1.67 & 1119 & 1122 [32] & 3.0 & 1.42 \\
\hline 4 & $\beta$-pinene & 968 & 974 [29] & 3.5 & 1.37 & 1106 & 1105 [30] & 2.9 & 1.06 \\
\hline 5 & $\alpha$-terpinene & 1012 & 1014 [29] & trace & - & 1176 & 1178 [32] & trace & - \\
\hline 6 & limonene & 1024 & 1024 [29] & 2.6 & 2.91 & 1198 & 1198 [32] & 1.8 & 2.68 \\
\hline 7 & 1,8-cineole & 1026 & 1026 [29] & 1.3 & 1.92 & 1205 & 1211 [32] & 1.2 & 2.04 \\
\hline 8 & terpinolene & 1078 & 1086 [29] & trace & - & 1280 & 1282 [32] & trace & - \\
\hline 9 & linalool & 1101 & 1095 [29] & 0.5 & 0.59 & 1554 & $1543[32]$ & 0.6 & 0.61 \\
\hline 10 & 1-ethenyl-4-methoxy-benzene & 1147 & $1154[33]$ & 1.6 & 0.04 & 1679 & $1670[34]$ & 0.3 & 0.02 \\
\hline 11 & citronellal & 1151 & 1148 [29] & 1.0 & 0.02 & 1448 & 1469 e & 0.8 & 0.02 \\
\hline 12 & cis-pinocamphone & 1167 & 1172 [29] & 0.8 & 1.09 & 1537 & 1545 [32] & 1.2 & 1.08 \\
\hline 13 & Terpinen-4-ol & 1174 & $1174[29]$ & 0.6 & 0.41 & 1600 & $1601[32]$ & 0.2 & 0.35 \\
\hline 14 & $\alpha$-terpineol & 1191 & $1186[29]$ & 0.3 & 0.30 & 1672 & 1694 [32] & 0.3 & 0.04 \\
\hline 15 & methyl geranate & 1320 & $1322[29]$ & 1.0 & 0.03 & - & - & - & - \\
\hline 16 & $\alpha$-copaene & 1363 & 1374 [29] & 10.5 & 0.36 & 1483 & 1491 [32] & 8.0 & 0.38 \\
\hline 17 & $\beta$-bourbonene & 1369 & 1387 [29] & 9.9 & 0.32 & 1509 & $1523[31]$ & 8.2 & 0.36 \\
\hline 18 & (Z)- $\beta$-caryophyllene & 1389 & 1408 [29] & 2.7 & 0.06 & 1565 & 1588 [32] & 0.9 & 0.14 \\
\hline 19 & (E)- $\beta$-caryophyllene & 1403 & 1417 [29] & 17.8 & 1.26 & 1587 & 1599 [32] & 14.5 & 1.30 \\
\hline 20 & $\beta$-cubebene & 1414 & 1387 [29] & 2.0 & 0.03 & 1580 & $1580[35]$ & 0.6 & 0.04 \\
\hline 21 & $\alpha$-humulene & 1438 & 1452 [29] & 0.9 & 0.08 & 1658 & $1667[32]$ & 1.2 & 0.07 \\
\hline 22 & cis-cadina-1(6),4-diene & 1466 & $1461[29]$ & 6.4 & 0.41 & 1664 & - & 6.2 & 0.05 \\
\hline 23 & germacrene D & 1480 & 1480 [29] & 4.9 & 0.65 & 1669 & $1674^{\mathrm{e}}$ & 4.9 & 0.72 \\
\hline 24 & $\delta$-cadinene & 1506 & $1522[29]$ & 6.6 & 0.28 & 1751 & 1756 [32] & 5.4 & 0.47 \\
\hline 25 & elemol & 1539 & 1548 [29] & 2.1 & 0.78 & 2079 & 2079 [32] & 1.5 & 1.75 \\
\hline 26 & hedycaryol & 1542 & 1546 [29] & 0.1 & 0.10 & 2046 & $2037[36]$ & 1.2 & 0.48 \\
\hline 27 & spathulenol & 1562 & 1577 [29] & 0.9 & 0.33 & 2119 & $2121[32]$ & 1.4 & 1.60 \\
\hline 28 & 10-epi- $\gamma$-eudesmol & 1618 & 1622 [29] & 1.8 & 0.51 & 2164 & $2170[31]$ & 1.3 & 0.24 \\
\hline 29 & caryophylla-4(12),8(13)-dien-5 $\beta$-ol & 1621 & 1639 [29] & 0.4 & 0.62 & 2292 & 2299 [37] & 1.6 & 0.54 \\
\hline 30 & $\beta$-eudesmol & 1638 & 1652 [29] & 1.0 & 1.11 & 2222 & $2220[31]$ & 1.1 & 0.31 \\
\hline 31 & $\gamma$-eudesmol & 1639 & $1630[29]$ & 1.7 & 0.37 & - & - & - & - \\
\hline 32 & unknown $(\mathrm{mw}=204)$ & - & - & - & - & 1697 & - & 2.1 & 0.36 \\
\hline 33 & bicyclogermacrene & - & - & - & - & 1723 & 1735 [32] & 2.6 & 1.02 \\
\hline 34 & caryophyllene oxide & - & - & - & - & 1968 & $1970[31]$ & 3.0 & 0.42 \\
\hline 35 & unknown $(\mathrm{mw}=220)$ & - & - & - & - & 2144 & - & 2.1 & 0.66 \\
\hline 36 & $\alpha$-eudesmol & 1651 & 1652 [29] & 1.3 & 0.30 & 2214 & 2223 [32] & 1.3 & 0.31 \\
\hline 37 & unknown $(\mathrm{mw}=204)$ & - & - & - & - & 2247 & - & 4.2 & 2.21 \\
\hline & Monoterpene hydrocarbons & & & 10.0 & & & & 8.1 & \\
\hline & Oxygenated monoterpene & & & 5.5 & & & & 4.3 & \\
\hline & Sesquiterpene hydrocarbons & & & 61.7 & & & & 58.8 & \\
\hline & Oxygenated sesquiterpene & & & 9.3 & & & & 14.5 & \\
\hline & Others & & & 1.6 & & & & 0.3 & \\
\hline & Total amount & & & 88.1 & & & & 86.0 & \\
\hline
\end{tabular}

${ }^{\mathrm{a}}$ Calculated linear retention index $(\mathrm{LRI}) ;{ }^{\mathrm{b}}$ reference linear retention index; ${ }^{\mathrm{c}}$ content; ${ }^{\mathrm{d}}$ standard deviation; trace $\sigma 0.1 \%$; mw $=$ molecular weight; ${ }^{e}$ identification confirmed by injection of original standards by one of the authors (B.S.).

\subsection{Enantioselective Analysis}

The enantioselective analysis was carried out on a 30\% diethyl-tert-butyldimethylsilyl$\beta$-cyclodextrin in a PS-086 capillary column. A total of nine chiral components were identified, eight of them were monoterpenoids and one a sesquiterpene hydrocarbon. None of the detected chiral compounds were enantiomerically pure. The results of the enantioselective analysis are reported in Table 2 and in Figure 1. 
Table 2. Enantioselective analysis of some chiral constituents of C. taxifolium EO on diethyl-tertbutyldimethylsilyl- $\beta$-cyclodextrin column.

\begin{tabular}{|c|c|c|c|c|}
\hline Component & $\mathrm{RT}^{\mathrm{a}}$ (min.) & LRI $^{b}$ & Enantiomer Percentage & $e e \%$ \\
\hline$(1 S, 5 R)-(+)-\alpha$-thujene ${ }^{c}$ & 12.96 & 920 & 16.1 & \multirow{2}{*}{67.8} \\
\hline$(1 R, 5 S)-(-)-\alpha$-thujene ${ }^{\mathrm{c}}$ & 13.20 & 924 & 83.9 & \\
\hline$(1 R, 5 R)-(+)-\alpha$-pinene & 13.72 & 933 & 92.8 & \multirow{2}{*}{85.5} \\
\hline$(1 S, 5 S)-(-)-\alpha$-pinene & 13.85 & 935 & 7.2 & \\
\hline$(1 R, 5 R)-(+)-\beta$-pinene & 15.28 & 959 & 5.0 & \multirow{2}{*}{90.0} \\
\hline$(1 S, 5 S)-(-)-\beta$-pinene & 15.76 & 967 & 94.9 & \\
\hline$(1 R, 5 R)-(+)$-sabinene & 16.85 & 985 & 43.9 & \multirow{2}{*}{12.3} \\
\hline$(1 S, 5 S)-(-)$-sabinene & 17.66 & 998 & 56.2 & \\
\hline$(S)-(-)$-limonene & 21.55 & 1061 & 94.1 & \multirow[b]{2}{*}{88.1} \\
\hline$(R)-(+)$-limonene & 22.59 & 1078 & 5.9 & \\
\hline$(R)-(-)$-linalool & 29.84 & 1198 & 33.7 & \multirow{2}{*}{32.7} \\
\hline (S)-(+)-linalool & 30.47 & 1209 & 66.3 & \\
\hline$(S)$-(+)-terpinen-4-ol & 33.98 & 1270 & 45.4 & \multirow[b]{2}{*}{9.3} \\
\hline$(R)-(-)$-terpinen-4-ol & 34.12 & 1272 & 54.6 & \\
\hline$(S)-(-)$ - $\alpha$-terpineol & 36.37 & 1312 & 85.6 & \multirow{2}{*}{71.2} \\
\hline$(R)-(+)$ - $\alpha$-terpineol & 37.13 & 1326 & 14.4 & \\
\hline$(R)-(+)$-germacrene D & 38.74 & 1354 & 5.5 & \multirow{2}{*}{89.0} \\
\hline$(S)-(-)$-germacrene D & 45.15 & 1474 & 94.5 & \\
\hline
\end{tabular}

$\overline{{ }^{a}}$ Retention time (RT); ${ }^{\text {b }}$ Linear Retention Index (LRI) calculated on the $30 \%$ diethyl-tert-butyldimethylsilyl- $\beta$ cyclodextrin in PS-086 column; ${ }^{c}$ tentative enantiomer identification according to [38]; $e e=$ enantiomeric excess.

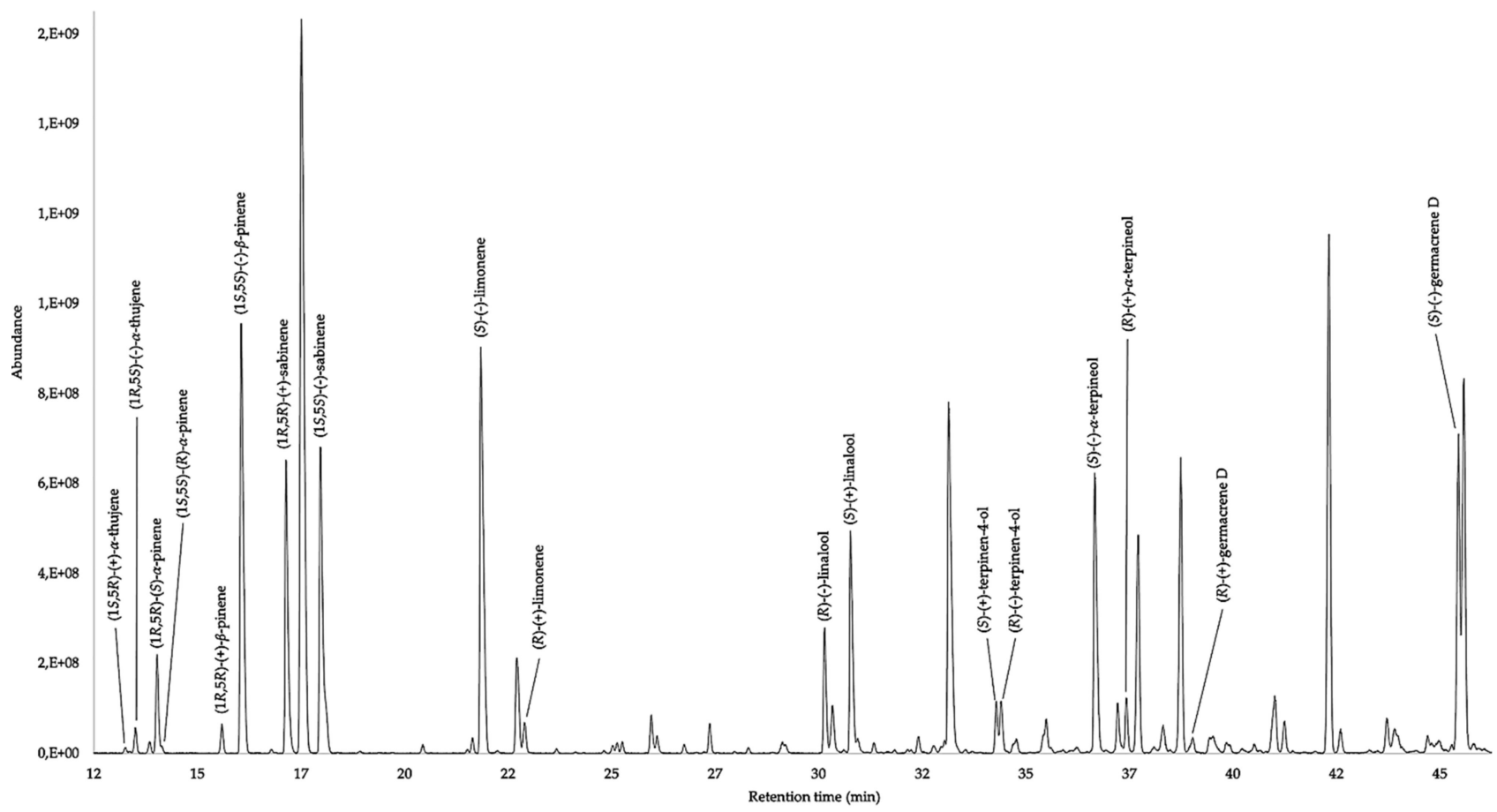

Figure 1. Enantioselective chromatogram of C. taxifolium EO on 30\% diethyl-tert-butyldimethylsilyl- $\beta$-cyclodextrin/PS-086 column.

\subsection{Cholinesterase Inhibition Test}

The inhibitory activity of $C$. taxifolium $\mathrm{EO}$ against $\mathrm{BChE}$ showed an $\mathrm{IC}_{50}$ value of $31.3 \pm 3.0 \mu \mathrm{g} / \mathrm{mL}$; however, it was shown to be inactive against $\mathrm{AChE}\left(\mathrm{IC}_{50}>250 \mu \mathrm{g} / \mathrm{mL}\right)$ (Figure 2). These results were compared to the ones of donepezil as positive control, which showed an $\mathrm{IC}_{50}$ value of about one order of magnitude less against $\mathrm{BChE}$. 

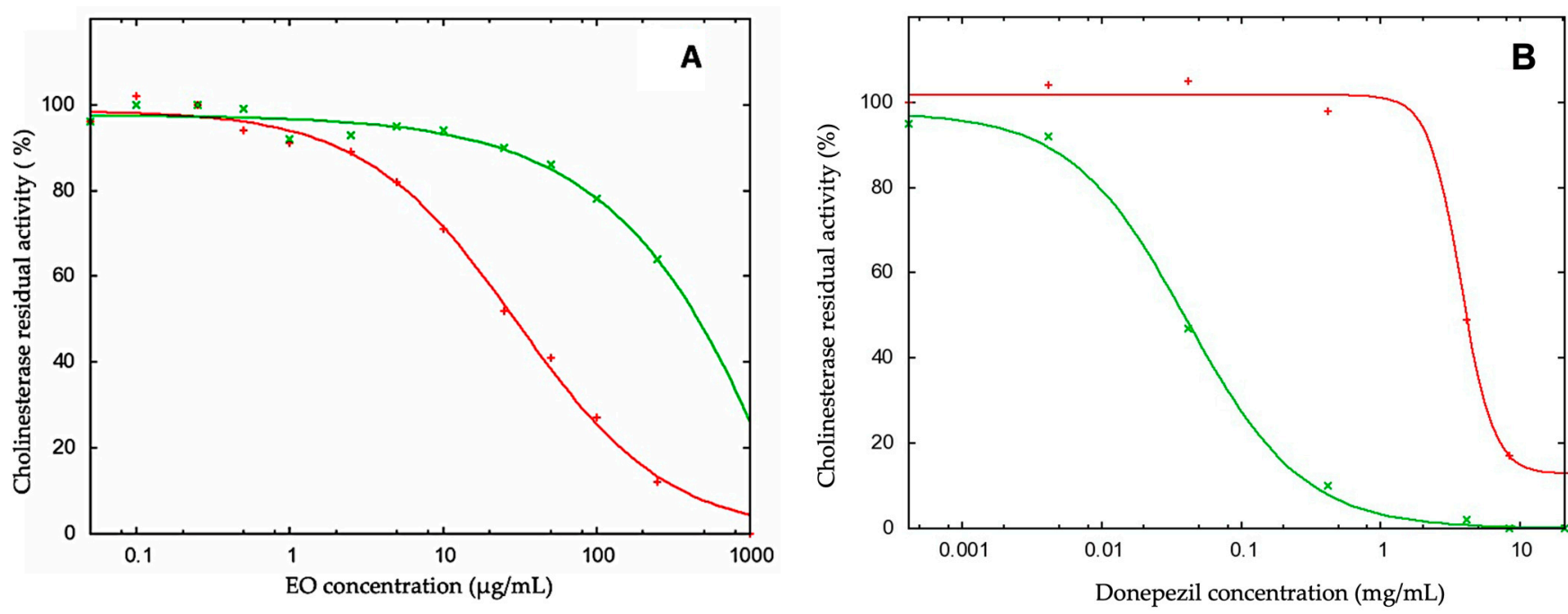

Figure 2. Half maximal inhibition concentration $\left(\mathrm{IC}_{50}\right)$ of $C$. taxifolium essential oil (A) and donepezil (B) against $\mathrm{AChE}$ (green curve) and BChE (red curve).

\section{Discussion}

\subsection{Selective BChE Inhibition Activity}

The activities on the Central Nervous System (CNS) are not usually investigated for the EOs [39], due to antibacterial and antifungal properties being the most common. Nevertheless, the literature reports several volatile fractions with an interesting in vitro inhibition activity $[24,40,41]$ versus $\mathrm{AChE}$ and $\mathrm{BChE}$. Some of them are also significantly active against $\mathrm{AD}$ in vivo, or even in clinical trials [24]. The secondary metabolites that have been recognized to be active as pure compounds are linalool, $\alpha$-terpinene, carvacrol, $\alpha$-terpineol, thymol, $\alpha$-pinene, (E)- $\beta$-caryophyllene and eugenol [24]. Five of them are also present in the investigated $\mathrm{EO}$ of $C$. taxifolium, where $(E)-\beta$-caryophyllene is the main constituent with an abundance of $17.8-14.5 \%$ on the two columns, respectively. However, the $C$. taxifolium $\mathrm{EO}$ produced a selective inhibition of $\mathrm{BChE}$, differing from what is usually described in the literature, where (E)- $\beta$-caryophyllene, and some of the above mentioned terpenoids, inhibit both enzymes [41]. Actually, the selective inhibition of $\mathrm{BChE}$ is a very interesting property, since many studies have been investing the clinical application of similar drugs during the last 20 years [42-44]. AChE and BChE are both present in the CNS but in different locations. In particular, AChE is typically found in neurons, whereas $\mathrm{BChE}$ is common in glial cells [42]. In normal brain, about $80 \%$ of the total cholinesterase is constituted by AChE, and only $20 \%$ by BChE. However, with the progress of the AD, the ratio between the activities of $\mathrm{BChE}$ and $\mathrm{AChE}$ can increase from the normal value of 0.5 up to 11 [42]. This phenomenon could convert $\mathrm{BChE}$ to the main $\mathrm{ChE}$ in the development of AD. From a speculative point of view, the inhibition mechanism for C. taxifolium EO can be explained considering the different shapes of the active sites. According to X-ray diffraction data, the selective activity can be achieved by using the additional space present in the active site of $\mathrm{BChE}$ [42], which implies that selective inhibitors are usually bigger molecules than those of AChE. Since this is not the case for $C$. taxifolium EO components, the most probable hypothesis is a synergic effect of the whole mixture, where the combined effect of many constituents is different from that of the sum of the same pure components. This behaviour has already been demonstrated for some essential oils and described in the literature, e.g., for Salvia lavandulifolia and Melaleuca alternifolia (tea tree) EOs [45,46]. The other major EO constituents were $\alpha$-copaene (10.5-8.0\%), $\beta$-bourbonene (9.9-8.2\%), $\delta$-cadinene (6.6-5.4\%), cis-cadina-1(6),4-diene (6.4-6.2\%) and germacrene D (4.9-4.9\%). These components can be responsible for the selective synergic effect, although, to the best of the authors' knowledge, no evidence has been reported in this respect. Although the $\mathrm{IC}_{50}$ value calculated for this $\mathrm{EO}$ is quite higher than the one calculated for the positive 
control, the EO can be considered an active product. In fact, donepezil (positive control) is a pure substance while the $\mathrm{EO}$ is a mixture of at least 37 compounds, most of them likely inactive.

\subsection{Enantiomeric Abundance and Biological Activity}

A second important factor influencing the biological activity of a complex mixture is the enantiomeric composition of its chiral components [47-49], which makes their recognition a step necessary for a correct definition of its chemistry and biological activity. The enantiomeric excess of the chiral compounds is also important to characterize another fundamental property of an EO, i.e., its olfactive profile [50]. The C. taxifolium EO was therefore analyzed by enantioselective GC-MS (Es-GC-MS), to determine the enantiomeric excess $(e e \%)$ of eight chiral monoterpenoids and one sesquiterpene hydrocarbon, resulting in the following $e e \%$ values: $(1 R, 5 S)-(-)-\alpha$-thujene $(67.8 \%),(1 R, 5 R)-(+)-\alpha$-pinene $(85.5 \%),(1 S, 5 S)-(-)-$ $\beta$-pinene (90.0\%), (1S,5S)-(-)-sabinene (12.3\%), (S)-(-)-limonene (88.1\%), (S)-(+)-linalool $(32.7 \%),(R)-(-)$-terpinen-4-ol (9.3\%), (S)-(-)- $\alpha$-terpineol (71.2\%) and $(S)-(-)$-germacrene D $(89.0 \%)$.

\subsection{Novel EO Chemical Profile in C. taxifolium}

Regarding the different chemical profile, compared to the one previously described, most of the essential oils of the genus Clinopodium present in the literature can be divided into three main categories: (i) EOs based on oxygenated monoterpenoids, (ii) EOs based on sesquiterpenes and sesquiterpenoids, and (iii) EOs based on both classes of metabolites. The first group is absolutely dominant, and it can be considered typical for the composition of Clinopodium essential oils. It is characterized by a fresh and minty aroma, sometimes phenolic. Pulegone, isopulegone, piperitone, piperitenone, piperitenone oxide, menthone, isomenthone and menthol are the main constituents. 1,8-Cineole, menthofuran, carvacrol, thymol, linalool and their derivatives can also seldom be found [51-65]. The second group is decidedly less common, and includes species like Clinopodium umbrosum (M.Bieb.) Kuntze and Clinopodium gracile (Benth) Matsum, whose EO major components are (E)- $\beta$-caryophyllene, germacrene $\mathrm{D}$, spathulenol, $\beta$-elemene, $\alpha$-bergamotene and cis- $\beta$ farnesene, among others [66,67]. The third type of EO is very rare and it is characterized by the presence of major compounds of both monoterpene and sesquiterpene. This is the case for Clinopodium chinense (Benth.) Kuntze, whose volatile fraction contains, most prevalently, piperitone, (E)- $\beta$-caryophyllene and spathulenol [68]. According to this classification, the chemical composition of the volatile fraction described in this study clearly fits with the second EO profile, since (E)- $\beta$-caryophyllene (17.8-14.5\%), $\alpha$-copaene (10.5-8.0\%), $\beta$-bourbonene (9.9-8.2\%), $\delta$-cadinene (6.6-5.4\%), cis-cadina-1(6),4-diene (6.4-0.2\%) and germacrene D (4.9-4.9\%) are the most abundant constituents. Nevertheless, the EO described in 2018 for C. taxifolium belongs to the first group [10]. Therefore, two quite different chemical profiles of $C$. taxifolium EO can be hypothesized, with the one described here probably being rarer.

\section{Materials and Methods}

\subsection{Materials and Equipment}

The chemical analyses were run by gas chromatography-mass spectrometry (GC-MS), with a 6890N GC unit from Agilent Technologies, coupled with a quadrupole Mass Spectrometry Detector (MSD) 5973 (Santa Clara, CA, USA). The MSD was operated with an electronic ionization $(70 \mathrm{eV})$ source, in scan mode, with a mass range detection of $35-350 \mathrm{~m} / \mathrm{z}$. The MS transfer line and ion source temperatures were $280^{\circ} \mathrm{C}$ and $200{ }^{\circ} \mathrm{C}$, respectively. The analyses were carried out with a non-polar DB-5ms capillary column (5\%-phenyl-methylpolysiloxane, $30 \mathrm{~m}$ length, $0.25 \mathrm{~mm}$ internal diameter and $0.25 \mu \mathrm{m}$ film thickness; J \& W Scientific, Folsom, CA, USA) and a polar HP-INNOWax column (polyethylene glycol, $30 \mathrm{~m}$ length, $0.25 \mathrm{~mm}$ internal diameter and $0.25 \mu \mathrm{m}$ film thickness; Agilent Technologies, Santa Clara, CA, USA). 
Quantitative analyses were carried out with a 6890N GC-FID system from Agilent Technologies (Santa Clara, CA, USA), equipped with a 7683 autoinjector also from Agilent Technologies (Little Falls, DE, USA). Linear retention indices were calculated through a homologous series of linear alkanes, from $n$-nonane to $n$-pentacosane $\left(C_{9}\right.$ purity $99 \%$ from BDH, Dubai, UAE; $\mathrm{C}_{10}-\mathrm{C}_{25}$ purity $99 \%$ from Sigma-Aldrich, St. Louis, MO, USA).

The enantiomeric excesses of chiral components were determined with an enantioselective column based on 30\% diethyl-tert-butydimethylsilyl- $\beta$-cyclodextrin diluted in PS-086. (length: $25 \mathrm{~m}$, internal diameter: $0.25 \mathrm{~mm}$, film thickness: $0.25 \mu \mathrm{m}$, from Mega, Legnano, Italy).

All the analytical grade (purity $>99 \%$ ) solvents, 5,5'-dithiobis-2-nitrobenzoic acid (DNTB), Electrophorus electricus acetylcholinesterase (Type VS, freeze-dried powder, $744 \mathrm{U} / \mathrm{mg}$ solid, $1272 \mathrm{U} / \mathrm{mg}$ protein), equine serum butyrylcholinesterase (lyophilized powder, 900 units / mg protein) and acetylthiocholine iodide were purchased from SigmaAldrich. A Varioskan Flash detection system was used for enzymatic inhibition experiments (Thermo Fisher Scientific, Waltham, MA, USA). Donepezil (purity >98\%) was used as positive control of ChE inhibition (Sigma-Aldrich).

\subsection{Plant Material}

The aerial parts of C. taxifolium were collected on 24 May 2018 in the province of Loja, mount Villonaco, at an altitude of $2724 \mathrm{~m}$ above sea level. The geographic point was located at coordinates $004^{\circ} 00^{\prime} 00^{\prime \prime} \mathrm{S}-079^{\circ} 17^{\prime} 00^{\prime \prime} \mathrm{W}$. In order to grant a statistically representative number of samples, five different specimens were collected within a radius of $500 \mathrm{~m}$ from these coordinates. The plant was collected with the permission of the Ministry of Environment of Ecuador (MAE-DNB-CN-2016-0048) and the specimens were identified by one of the authors (N.C.). A voucher specimen was also deposited inside the Universidad Técnica Particular de Loja herbarium (herbarium code: HUTPL), with the identification code VMZ_010. To ensure the correct botanical identification, both the current and the previous specimens (voucher $n$. PPN-la-101) were compared with an original sample from the herbarium of the Universidad Nacional de Loja (herbarium code: LOJA), with all showing morphologically identical results.

\subsection{Isolation of the Essential Oil and Samples Preparation}

Five analytical hydrodistillations were performed on the fresh aerial parts of each botanical specimen. These processes were carried out with a glass laboratory-scale Marcusson apparatus, with recycling of the lower phase. During each analytical distillation, seventeen grams of fresh plant material were hydrodistilled for $90 \mathrm{~min}$ and the essential oil collected in $500 \mu \mathrm{L}$ of an extraction layer of cyclohexane, containing $n$-nonane as internal standard $(0.7 \mathrm{mg} / \mathrm{mL})$. The cyclohexane layers were recovered and directly injected for GC analyses.

After verifying the similarity of the five chemical patterns, the entire remaining plant material was gathered to perform a preparative distillation. For this purpose, $1.6 \mathrm{~kg}$ of fresh plant material were hydrodistilled for $4 \mathrm{~h} \mathrm{[69],} \mathrm{with} \mathrm{a} \mathrm{stainless-steel} \mathrm{Clevenger-type}$ apparatus, obtaining a pure essential oil that separated spontaneously from the water phase.

All samples were stored in amber vials at $-15^{\circ} \mathrm{C}$. The pure essential oil was used for biological tests, while the 5 laboratory-scale repetitions were used for chemical and enantioselective analyses.

\subsection{Qualitative Chemical Analysis}

The GC-MS analyses on DB-5ms were carried out under the following conditions: carrier gas: helium, constant flow rate: $1 \mathrm{~mL} / \mathrm{min}$; injection volume: $1 \mu \mathrm{L}$, injection mode: split (ratio of 40:1), injection temperature: $250{ }^{\circ} \mathrm{C}$; temperature program: from $50{ }^{\circ} \mathrm{C}(1 \mathrm{~min})$ to $250{ }^{\circ} \mathrm{C}(10 \mathrm{~min})$ at $3{ }^{\circ} \mathrm{C} / \mathrm{min}$. Analyses on the HP-INNOWax column were carried out under the same conditions as for DB-5ms, only the final oven temperature was set at $230^{\circ} \mathrm{C}$. 
The EO components were identified by comparing both their linear retention indices (LRIs), calculated according to Van Den Dool and Kratz [70], and their mass spectra to those reported in the literature and, where available, with authentic standards (see Table 1).

\subsection{Abundance Chemical Analysis}

The abundance analyses were carried out under the same instrumental conditions as those adopted above, with the exception of the temperature program: from $50^{\circ} \mathrm{C}(1 \mathrm{~min})$ to $180^{\circ} \mathrm{C}$ at the rate of $3{ }^{\circ} \mathrm{C} / \mathrm{min}$, then $15^{\circ} \mathrm{C} / \mathrm{min}$ until $250{ }^{\circ} \mathrm{C}(15 \mathrm{~min})$ for $\mathrm{DB}-5 \mathrm{~ms}$ and $230^{\circ} \mathrm{C}(15 \mathrm{~min})$ for HP-INNOWax. FID conditions: hydrogen flowrate $30 \mathrm{~mL} / \mathrm{min}$, air flow $300 \mathrm{~mL} / \mathrm{min}$, temperature: $250{ }^{\circ} \mathrm{C}$. The abundance composition was obtained by using relative response factors, calculated on the basis of the combustion enthalpy [71] and taking isopropyl caproate as a calibration standard. Isopropyl caproate was obtained by synthesis in one of the authors' laboratory (G.G.) and its purity was $97 \%$ by GC. Furthermore, a calibration curve was constructed for each column. Six calibration standard dilutions were taken to build-up the calibration curves, corresponding to $0.6,1.8,4.3,8.3,16.8$ and $34.3 \mathrm{mg}$ of isopropyl caproate in $10 \mathrm{~mL}$ of cyclohexane, respectively. Nonane $(7.0 \mathrm{mg})$ was used as internal standard. The calibration curves generated a correlation coefficient of 0.999 for both columns.

\subsection{Enantioselective GC Analysis}

The enantioselective GC-MS analysis was performed with a temperature program from $50{ }^{\circ} \mathrm{C}(5 \mathrm{~min})$ to $220{ }^{\circ} \mathrm{C}(5 \mathrm{~min})$ at $2{ }^{\circ} \mathrm{C} / \mathrm{min}$. The elution order was established by injecting, in the same instrumental conditions, mixtures of enantiomerically pure standards, available in one of the authors' laboratory (C.B.).

\subsection{Cholinesterase Inhibition Test}

The activities against cholinesterase (ChE) were evaluated by a colorimetric protocol, adapted from Ellman et al. [72]. The catalyst efficiently hydrolyzes acetylthiocholine (ATCh), the sulphur analogue of the natural substrate of these enzymes. After hydrolysis, this substrate analogue produces acetate ion and thiocoline. Thiocoline, in the presence of the highly reactive dithiobisnitrobenzoate ion (DTNB), produces a yellow color, which can be monitored quantitatively by its spectrophotometric absorption at $412 \mathrm{~nm}$. The inhibition assay volume contained $200 \mu \mathrm{L}$ of phosphate buffered saline (pH 7.4), DNTB (1.5 mM) and test sample in DMSO $(1 \% v / v)$. Both Electrophorus electricus acetylcholinesterase and equine serum butyrylcholinesterase were dissolved in PBS pH 7.4 and were used at $25 \mathrm{mU} / \mathrm{mL}$ for the assay. After $10 \mathrm{~min}$ of preincubation, the substrate acetylthiocholine iodide $(1.5 \mathrm{mM})$ was added to start the reaction. During the incubation at $30{ }^{\circ} \mathrm{C}$ for $30 \mathrm{~min}$, multiple 96 -well microliter sites were read in a Varioskan Flash detection system. All measurements were run in triplicate. When possible, the $\mathrm{IC}_{50}$ values were calculated using the GNUPLOT package online (www.ic50.tk, www.gnuplot.info). Donepezil was used as reference ChE inhibitor, with an $\mathrm{IC}_{50}=100 \mathrm{nM}$ for $\mathrm{AChE}$ and $8500 \mathrm{nM}$ for BChE. In this assay, the possibility of false positive inhibition results, previously described for high concentration ( $>100 \mu \mathrm{g} / \mathrm{mL}$ ) of amine or aldehyde compounds, cannot be excluded [73].

\section{Conclusions}

The aerial parts of the native Andean species Clinopodium taxifolium (Kunth) Govaerts (Lamiaceae) give an EO mainly consisting of sesquiterpenes and sesquiterpenoids. Although rather uncommon, the composition based on sesquiterpenoids has already been described for other species belonging to Clinopodium genus. In this case, it indicates the existence of at least two chemical profiles for C. taxifolium. This EO is characterized by a selective inhibition activity versus the enzyme $\mathrm{BChE}$. The interest in a selective inhibitor is justified by the relative overexpression of this enzyme in the advanced progression of the AD. The search for this kind of inhibitor, over the last 20 years, testifies to the importance of this matter in pharmaceutical research. However, in our case, the relatively small size 
and the aliphatic structure of the molecules suggest a possible synergic mechanism instead of the presence of a single inhibitor in the mixture. This problem is possibly the main item to be investigated for this $\mathrm{EO}$ in future research.

Author Contributions: Conceptualization, G.G.; data curation, G.G. and J.R.; investigation, S.E., B.S., N.B., N.C.; supervision, G.G.; writing—original draft, S.E.; writing—review and editing, G.G., C.B., and C.L. All authors have read and agreed to the published version of the manuscript.

Funding: This research received no external funding.

Data Availability Statement: The data presented in this study are available on request from the authors.

Acknowledgments: We are grateful to the Universidad Técnica Particular de Loja (UTPL) for supporting this investigation and open access publication.

Conflicts of Interest: The authors declare no conflict of interest.

\section{References}

1. Megadiverse Countries. UNEP-WCMC. 2014. Available online: https://www.biodiversitya-z.org/content/megadiversecountries (accessed on 22 December 2020).

2. Malagón, O.; Ramírez, J.; Andrade, J.M.; Morocho, V.; Armijos, C.; Gilardoni, G. Phytochemistry and Ethnopharmacology of the Ecuadorian Flora. A Review. Nat. Prod. Commun. 2016, 11, 297-314. [CrossRef] [PubMed]

3. Chiriboga, X.; Gilardoni, G.; Magnaghi, I.; Finzi, P.V.; Zanoni, G.; Vidari, G. New Anthracene Derivatives from Coussareamacrophylla. J. Nat. Prod. 2003, 66, 905-909. [CrossRef] [PubMed]

4. Quílez, A.; Berenguer, B.; Gilardoni, G.; Souccar, C.; De Mendonça, S.; Oliveira, L.F.S.; Martin-Calero, M.J.; Vidari, G. Antisecretory, anti-inflammatory and anti-Helicobacter pylori activities of several fractions isolated from Piper carpunya Ruiz \& Pav. J. Ethnopharmacol. 2010, 128, 583-589. [CrossRef] [PubMed]

5. Gilardoni, G.; Tosi, S.; Mellerio, G.; Maldonado, M.; Chiriboga, X.; Vidari, G. Lipophilic Components from the Ecuadorian Plant Schistocarpha eupatoroides. Nat. Prod. Commun. 2010, 6, 767-772.

6. Gilardoni, G.; Chiriboga, X.; Finzi, P.V.; Vidari, G. New 3,4-Secocycloartane and 3,4-Secodammarane Triterpenes from the Ecuadorian Plant Coussarea macrophylla. Chem. Biodivers. 2015, 12, 946-954. [CrossRef]

7. Armijos, C.; Gilardoni, G.; Amay, L.; Lozano, A.; Bracco, F.; Ramírez, J.; Bec, N.; Larroque, C.; Finzi, P.V.; Vidari, G. Phytochemical and ethnomedicinal study of Huperzia species used in the traditional medicine of Saraguros in Southern Ecuador; AChE and MAO inhibitory activity. J. Ethnopharmacol. 2016, 193, 546-554. [CrossRef]

8. Torres-Naranjo, M.; Suárez, A.I.; Gilardoni, G.; Cartuche, L.; Flores, P.; Morocho, V. Chemical Constituents of Muehlenbeckia tamnifolia (Kunth) Meisn (Polygonaceae) and Its In Vitro $\alpha$-Amilase and $\alpha$-Glucosidase Inhibitory Activities. Molecules 2016, 21, 1461. [CrossRef]

9. Ramírez, J.; Suarez, A.I.; Bec, N.; Armijos, C.; Gilardoni, G.; Larroque, C.; Vidari, G. Carnosol from Lepechinia mutica and tiliroside from Vallea stipularis: Two promising inhibitors of BuChE. Rev. Bras. Farmacogn. 2018, 28, 559-563. [CrossRef]

10. Morocho, V.; Valle, A.; Gárcia, J.; Gilardoni, G.; Cartuche, L.; Suárez, A.I. $\alpha$-Glucosidase Inhibition and Antibacterial Activity of Secondary Metabolites from the Ecuadorian Species Clinopodium taxifolium (Kunth) Govaerts. Molecules 2018, 23, 146. [CrossRef]

11. Ramírez, J.; Gilardoni, G.; Jácome, M.; Montesinos, J.; Rodolfi, M.; Guglielminetti, M.L.; Cagliero, C.; Bicchi, C.; Vidari, G. Chemical Composition, Enantiomeric Analysis, AEDA Sensorial Evaluation and Antifungal Activity of the Essential Oil from the Ecuadorian PlantLepechinia muticaBenth(Lamiaceae). Chem. Biodivers. 2017, 14, e1700292. [CrossRef]

12. Calva, J.; Bec, N.; Gilardoni, G.; Larroque, C.; Cartuche, L.; Bicchi, C.; Montesinos, J.V. Acorenone B: AChE and BChE Inhibitor as a Major Compound of the Essential Oil Distilled from the Ecuadorian Species Niphogeton dissecta (Benth.) J.F. Macbr. Pharmaceuticals 2017, 10, 84. [CrossRef] [PubMed]

13. Herrera, C.; Morocho, V.; Vidari, G.; Bicchi, C.; Gilardoni, G. Phytochemical Investigation of Male and Female Hedyosmum scabrum (Ruiz \& Pav.) Solms Leaves from Ecuador. Chem. Biodivers. 2018, 15, e1700423. [CrossRef]

14. Ramírez, J.; Gilardoni, G.; Ramón, E.; Tosi, S.; Picco, A.M.; Bicchi, C.; Vidari, G. Phytochemical Study of the Ecuadorian Species Lepechinia mutica (Benth.) Epling and High Antifungal Activity of Carnosol against Pyricularia oryzae. Pharmaceuticals 2018, 11, 33. [CrossRef] [PubMed]

15. Gilardoni, G.; Ramírez, J.; Montalván, M.; Quinche, W.; León, J.; Benítez, L.; Morocho, V.; Cumbicus, N.; Bicchi, C. Phytochemistry of Three Ecuadorian Lamiaceae: Lepechinia heteromorpha (Briq.) Epling, Lepechinia radula (Benth.) Epling and Lepechinia paniculata (Kunth) Epling. Plants 2018, 8, 1. [CrossRef]

16. Espinosa, S.; Bec, N.; Larroque, C.; Ramírez, J.; Sgorbini, B.; Bicchi, C.; Gilardoni, G. Chemical, Enantioselective, and Sensory Analysis of a Cholinesterase Inhibitor Essential Oil from Coreopsis triloba S.F. Blake (Asteraceae). Plants 2019, 8, 448. [CrossRef]

17. Montalván, M.; Peñafiel, M.A.; Ramírez, J.; Cumbicus, N.; Bec, N.; Larroque, C.; Bicchi, C.; Gilardoni, G. Chemical Composition, Enantiomeric Distribution, and Sensory Evaluation of the Essential Oils Distilled from the Ecuadorian Species Myrcianthes myrsinoides (Kunth) Grifo and Myrcia mollis (Kunth) DC (Myrtaceae). Plants 2019, 8, 511. [CrossRef] 
18. Gárcia, J.; Gilardoni, G.; Cumbicus, N.; Morocho, V. Chemical Analysis of the Essential Oil from Siparuna echinata (Kunth) A. DC. (Siparunaceae) of Ecuador and Isolation of the Rare Terpenoid Sipaucin A. Plants 2020, 9, 187. [CrossRef]

19. Gilardoni, G.; Matute, Y.; Ramírez, J. Chemical and Enantioselective Analysis of the Leaf Essential Oil from Piper coruscans Kunth (Piperaceae), a Costal and Amazonian Native Species of Ecuador. Plants 2020, 9, 791. [CrossRef]

20. Gilardoni, G.; Montalván, M.; Ortiz, M.; Vinueza, D.; Montesinos, J.V. The Flower Essential Oil of Dalea mutisii Kunth (Fabaceae) from Ecuador: Chemical, Enantioselective, and Olfactometric Analyses. Plants 2020, 9, 1403. [CrossRef]

21. Tropicos. Clinopodium taxifolium (Kunth) Govaerts. 1999. Available online: https://www.tropicos.org/name/50199434 (accessed on 22 December 2020).

22. Harley, R.M.; Paucar, A.G. List of Species of Tropical American Clinopodium (Labiatae), with New Combinations. Kew Bull. 2000, 55, 917. [CrossRef]

23. Jorgensen, P.; Leon-Yanez, S. Catalogue of the Vascular Plants of Ecuador; Monogram St. Louis: St. Louis, MO, USA, 1999; Volume 75, p. 519.

24. Benny, A.; Thomas, J. Essential Oils as Treatment Strategy for Alzheimer's Disease: Current and Future Perspectives. Planta Med. 2018, 85, 239-248. [PubMed]

25. Hu, S.; Maiti, P.; Ma, Q.; Zuo, X.; Jones, M.R.; Cole, G.M.; Frautschy, S.A. Clinical development of curcumin in neurodegenerative disease. Expert Rev. Neurother. 2015, 15, 629-637. [CrossRef] [PubMed]

26. Dos Santos, T.C.; Gomes, T.M.; Pinto, B.A.S.; Camara, A.L.; Paes, A.M.A. Naturally Occurring Acetylcholinesterase Inhibitors and Their Potential Use for Alzheimer's Disease Therapy. Front. Pharmacol. 2018, 9, 1192. [CrossRef] [PubMed]

27. Casey, D.A.; Antimisiaris, D.; O’Brien, J. Drugs for Alzheimer's Disease: Are They Effective? Pharm. Ther. 2010, 35, $208-211$.

28. Hong, Y.J.; Choi, S.H.; Jeong, J.H.; Park, K.W.; Na, H.R. Effectiveness of Anti-Dementia Drugs in Extremely Severe Alzheimer's Disease: A 12-Week, Multicenter, Randomized, Single-Blind Study. J. Alzheimers Dis. 2018, 63, 1035-1044. [CrossRef]

29. Sparkman, O.D. Identification of essential oil components by gas chromatography/quadrupole mass spectroscopy Robert $P$. Adams. J. Am. Soc. Mass Spectrom. 2005, 16, 1902-1903. [CrossRef]

30. Saroglou, V.; Marin, P.D.; Rančić, A.; Veljic, M.; Skaltsa, H. Composition and antimicrobial activity of the essential oil of six Hypericum species from Serbia. Biochem. Syst. Ecol. 2007, 35, 146-152. [CrossRef]

31. Bisio, A.; Ciarallo, G.; Romussi, G.; Fontana, N.; Mascolo, N.; Capasso, R.; Biscardi, D. Chemical composition of essential oils from some Salvia species. Phytother. Res. 1998, 12, S117-S120. [CrossRef]

32. Babushok, V.I.; Linstrom, P.J.; Zenkevich, I.G. Retention Indices for Frequently Reported Compounds of Plant Essential Oils. J. Phys. Chem. Ref. Data 2011, 40, 043101. [CrossRef]

33. Zhao, C.-X.; Li, X.-N.; Liang, Y.-Z.; Fang, H.-Z.; Huang, L.-F.; Guo, F.-Q. Comparative analysis of chemical components of essential oils from different samples of Rhododendron with the help of chemometrics methods. Chemom. Intell. Lab. Syst. 2006, 82, 218-228. [CrossRef]

34. Ledauphin, J.; Saint-Clair, J.-F.; Lablanquie, O.; Guichard, H.; Founier, N.; Guichard, E.; Barillier, D. Identification of Trace Volatile Compounds in Freshly Distilled Calvados and Cognac Using Preparative Separations Coupled with Gas Chromatography-Mass Spectrometry. J. Agric. Food Chem. 2004, 52, 5124-5134. [CrossRef] [PubMed]

35. Salgueiro, L.; Pinto, E.; Gonçalves, M.J.; Costa, I.; Palmeira, A.; Cavaleiro, C.; Pina-Vaz, C.; Rodrigues, A.G.; Martinez-De-Oliveira, J. Antifungal activity of the essential oil of Thymus capitellatus against Candida, Aspergillus and dermatophyte strains. Flavour Fragr. J. 2006, 21, 749-753. [CrossRef]

36. Rubiolo, P.; Matteodo, M.; Riccio, G.; Ballero, M.; Christen, P.; Fleury-Souverain, S.; Veuthey, J.-L.; Bicchi, C. Analytical Discrimination of Poisonous and Nonpoisonous Chemotypes of Giant Fennel (Ferula communisL.) through Their Biologically Active and Volatile Fractions. J. Agric. Food Chem. 2006, 54, 7556-7563. [CrossRef] [PubMed]

37. Capetanos, C.; Saroglou, V.; Marin, P.D.; Simic, A.; Skaltsa, H. Essential oil analysis of two endemic Eryngium species from Serbia. J. Serbian Chem. Soc. 2007, 72, 961-965. [CrossRef]

38. Dugo, G.; Bonaccorsi, I.; Sciarrone, D.; Costa, R.; Dugo, P.; Mondello, L.; Santi, L.; Fakhry, H.A. Characterization of Oils from the Fruits, Leaves and Flowers of the Bitter Orange Tree. J. Essent. Oil Res. 2011, 23, 45-59. [CrossRef]

39. Dobetsberger, C.; Buchbauer, G. Actions of essential oils on the central nervous system: An updated review. Flavour Fragr. J. 2011, 26, 300-316. [CrossRef]

40. Loizzo, M.R.; Ben Jemia, M.; Senatore, F.; Bruno, M.; Menichini, F.; Tundis, R. Chemistry and functional properties in prevention of neurodegenerative disorders of five Cistus species essential oils. Food Chem. Toxicol. 2013, 59, 586-594. [CrossRef]

41. Bonesi, M.; Menichini, F.; Tundis, R.; Loizzo, M.R.; Conforti, F.; Passalacqua, N.; Statti, G.A.; Menichini, F. Acetylcholinesterase and butyrylcholinesterase inhibitory activity of Pinus species essential oils and their constituents. J. Enzym. Inhib. Med. Chem. 2010, 25, 622-628. [CrossRef]

42. Greig, N.H.; Utsuki, T.; Qian-sheng, Y.; Xiaoxiang, Z.; Holloway, H.W.; Perry, T.A.; Lee, B.; Ingram, D.K.; Lahiri, D.K. A New Therapeutic Target in Alzheimer's Disease Treatment: Attention to Butyrylcholinesterase. Curr. Med. Res. Opin. 2001, 17, 159-165. [CrossRef]

43. Greig, N.H.; Lahiri, D.K.; Sambamurti, K. Butyrylcholinesterase: An Important New Target in Alzheimer's Disease Therapy. Int. Psychogeriatr. 2002, 14, 77-91. [CrossRef]

44. Li, Q.; Yang, H.; Chen, Y.; Sun, H. Recent progress in the identification of selective butyrylcholinesterase inhibitors for Alzheimer's disease. Eur. J. Med. Chem. 2017, 132, 294-309. [CrossRef] [PubMed] 
45. Savelev, S.; Okello, E.; Perry, N.; Wilkins, R.; Perry, E. Synergistic and antagonistic interactions of anticholinesterase terpenoids in Salvia lavandulaefolia essential oil. Pharmacol. Biochem. Behav. 2003, 75, 661-668. [CrossRef]

46. Miyazawa, M.; Yamafuji, C. Inhibition of acetylcholinesterase activity by tea tree oil and constituent terpenoids. Flavour Fragr. J. 2006, 21, 198-201. [CrossRef]

47. Marriott, P.J.; Shellie, R.; Cornwell, C. Gas chromatographic technologies for the analysis of essential oils. J. Chromatogr. A 2001, 936, 1-22. [CrossRef]

48. König, W.A.; Hochmuth, D.H. Enantioselective Gas Chromatography in Flavor and Fragrance Analysis: Strategies for the Identification of Known and Unknown Plant Volatiles. J. Chromatogr. Sci. 2004, 42, 423-439. [CrossRef]

49. Liberto, E.; Cagliero, C.; Sgorbini, B.; Bicchi, C.; Sciarrone, D.; Zellner, B.D.; Mondello, L.; Rubiolo, P. Enantiomer identification in the flavor and fragrance fields by "interactive" combination of linear retention indices from enantioselective gas chromatography and mass spectrometry. J. Chromatogr. A 2008, 1195, 117-126. [CrossRef]

50. Brenna, E.; Fuganti, C.; Serra, S. Enantioselective perception of chiral odorants. Tetrahedron Asymmetry 2003, 14, 1-42. [CrossRef]

51. Dunkić, V.; Kremer, D.; Grubešić, R.J.; Rodríguez, J.V.; Ballian, D.; Bogunić, F.; Stešević, D.; Kosalec, I.; Bezić, N.; Stabentheiner, E. Micromorphological and phytochemical traits of four Clinopodium L. species (Lamiaceae). S. Afr. J. Bot. 2017, 11, 232-241. [CrossRef]

52. Reynoso, M.; Coca, M.E.B.; Brodkiewicz, I.Y.; Jaime, G.; Perotti, M.; Schuff, C.; Vera, N. Anti-inflammatory Effects and Safety of Extracts and Essential Oil from Clinopodium gilliesii (muña muña). Int. J. Pharm. Sci. Drug Res. 2018, 10, 306-314. [CrossRef]

53. Ali-Shtayeh, M.S.; Jamous, R.M.; Abu-Zaitoun, S.Y.; Akkawi, R.J.; Kalbouneh, S.; Bernstein, N.; Dudai, N. Chemical profile and bioactive properties of the essential oil isolated from Clinopodium serpyllifolium (M.Bieb.) Kuntze growing in Palestine. Ind. Crop. Prod. 2018, 124, 617-625. [CrossRef]

54. Arantes, S.M.; Piçarra, A.; Guerreiro, M.; Salvador, C.; Candeias, F.; Caldeira, A.T.; Martins, M.R. Toxicological and pharmacological properties of essential oils of Calamintha nepeta, Origanum virens and Thymus mastichina of Alentejo (Portugal). Food Chem. Toxicol. 2019, 133, 110747. [CrossRef] [PubMed]

55. Barbieri, N.; Costamagna, M.; Gilabert, M.; Perotti, M.; Schuff, C.; Isla, M.I.; Benavente, A. Antioxidant activity and chemical composition of essential oils of three aromatic plants from La Rioja province. Pharm. Biol. 2015, 54, 168-173. [CrossRef] [PubMed]

56. Gilardoni, G.; Malagón, O.; Morocho, V.; Negri, R.; Tosi, S.; Guglielminetti, M.; Vidari, G.; Finzi, P.V. Phytochemical researches and antimicrobial activity of Clinopodium nubigenum Kunth (Kuntze) raw extracts. Rev. Bras. Farmacogn. 2011, 21, 850-855. [CrossRef]

57. Matailo, A.; Bec, N.; Calva, J.; Ramírez, J.; Andrade, J.M.; Larroque, C.; Vidari, G.; Armijos, Ch. Selective BuChE inhibitory activity, chemical composition, and enantiomer content of the volatile oil from the Ecuadorian plant Clinopodium brownie. Rev. Bras. Farmacogn. 2019, 29, 749-754. [CrossRef]

58. Debbabi, H.; El Mokni, R.; Chaieb, I.; Nardoni, S.; Maggi, F.; Caprioli, G.; Hammami, S. Chemical Composition, Antifungal and Insecticidal Activities of the Essential Oils from Tunisian Clinopodium nepeta subsp. nepeta and Clinopodium nepeta subsp. glandulosum. Molecules 2020, 25, 2137. [CrossRef]

59. Paco, F.N.; Tatiana, D.L.; Ángeles, M.; Edison, A.O.; Pablo, G.; Andrea, F. Clinopodium nubigenum (Kunth) Kuntze essential oil: Chemical composition, antioxidant activity, and antimicrobial test against respiratory pathogens. J. Pharmacogn. Phytother. 2018, 10, 149-157. [CrossRef]

60. Retta, D.S.; Gonzalez, S.B.; Guerra, P.E.; van Baren, C.M.; Di Leo Lira, P.; Bandoni, A.L. Essential oils of native and naturalized Lamiaceae species growing in the Patagonia region (Argentina). J. Essent. Oil Res. 2017, 29, 64-75. [CrossRef]

61. Rojas-Olivos, A.; Solano-Gómez, R.; Granados-Echegoyen, C.; Santiago-Santiago, L.A.; García-Dávila, J.; Perez-Pacheco, R.; Lagunez-Rivera, L. Larvicidal effect of Clinopodium macrostemum essential oil extracted by microwave-assisted hydrodistillation against Culex quinquefasciatus (Diptera: Culicidae). Rev. Soc. Bras. Med. Trop. 2018, 51, 291-296. [CrossRef]

62. Tepe, B.; Sihoglu-Tepe, A.; Daferera, D.; Polissiou, M.; Sokmen, A. Chemical composition and antioxidant activity of the essential oil of Clinopodium vulgare L. Food Chem. 2007, 103, 766-770. [CrossRef]

63. Villa-Ruano, N.; Pacheco-Hernández, Y.; Cruz-Durán, R.; Lozoya-Gloria, E. Volatiles and seasonal variation of the essential oil composition from the leaves of Clinopodium macrostemum var laevigatum and its biological activities. Ind. Crop. Prod. 2015, 77, 741-747. [CrossRef]

64. Benzo, M.; Gilardoni, G.; Gandini, C.; Caccialanza, G.; Finzi, P.V.; Vidari, G.; Abdo, S.; Layedra, P. Determination of the threshold odor concentration of main odorants in essential oils using gas chromatography-olfactometry incremental dilution technique. J. Chromatogr. A 2007, 1150, 131-135. [CrossRef] [PubMed]

65. Romani, R.; Bedini, S.; Salerno, G.; Ascrizzi, R.; Flamini, G.; Echeverria, M.C.; Farina, P.; Conti, B. Andean Flora as a Source of New Repellents against Insect Pests: Behavioral, Morphological and Electrophysiological Studies on Sitophilus zeamais (Coleoptera: Curculionidae). Insects 2019, 10, 171. [CrossRef] [PubMed]

66. Kumar, V.; Mathela, C.; Tewari, A.; Bisht, K. In vitro inhibition activity of essential oils from some Lamiaceae species against phytopathogenic fungi. Pestic. Biochem. Physiol. 2014, 114, 67-71. [CrossRef] [PubMed]

67. Chen, X.; Liu, X.; Zhou, L.; Liu, Z. Essential Oil Composition and Larvicidal Activity of Clinopodium gracile (Benth) Matsum (Labiatae) Aerial Parts against the Aedes albopictus Mosquito. Trop. J. Pharm. Res. 2013, 12, 799-804. [CrossRef]

68. Li, H.Y.; Liu, X.C.; Chen, X.B.; Liu, Q.Z.; Liu, Z.L. Chemical Composition and Insecticidal Activities of the Essential Oil of Clinopodium chinense (Benth.) Kuntze Aerial Parts against Liposcelis bostrychophila Badonnel. J. Food Prot. 2015, 78, 1870-1874. [CrossRef] 
69. Conde-Hernández, L.A.; Espinosa-Victoria, J.R.; Trejo, A.; Guerrero-Beltrã, J.A. $\mathrm{CO}_{2}$-supercritical extraction, hydrodistillation and steam distillation of essential oil of rosemary (Rosmarinus officinalis). J. Food Eng. 2017, 200, 81-86. [CrossRef]

70. Dool, H.V.D.; Kratz, P.D. A generalization of the retention index system including linear temperature programmed gas-liquid partition chromatography. J. Chromatogr. A 1963, 11, 463-471. [CrossRef]

71. Laumer, J.D.S.; Leocata, S.; Tissot, E.; Baroux, L.; Kampf, D.M.; Merle, P.; Boschung, A.; Seyfried, M.; Chaintreau, A. Prediction of response factors for gas chromatography with flame ionization detection: Algorithm improvement, extension to silylated compounds, and application to the quantification of metabolites. J. Sep. Sci. 2015, 38, 3209-3217. [CrossRef]

72. Ellman, G.L.; Courtney, K.; Andres, V.; Featherstone, R.M. A new and rapid colorimetric determination of acetylcholinesterase activity. Biochem. Pharmacol. 1961, 7, 88-95. [CrossRef]

73. Rhee, I.K.; Van Rijn, R.M.; Verpoorte, R. Qualitative determination of false-positive effects in the acetylcholinesterase assay using thin layer chromatography. Phytochem. Anal. 2003, 14, 127-131. [CrossRef]

Sample Availability: Samples of the compounds are not available from the authors. 